\title{
Chamber Orchestra in the Works by Viennese Classics
}

Emil M. Preisman* Krasnoyarsk State Academy of Music and Theatre 22 Lenin Str., Krasnoyarsk, 660045, Russia

Received 15.08.2014, received in revised form 30.08.2014, accepted 18.09.2014

The present article is dedicated to the evolution of chamber orchestra in works by Haydn, Mozart, and other composers. The article analyzes quantitative and timbre instrumentation of big and small orchestras of the given period and performed pieces. It interprets the terms of "nocturne", which stood for a category of functional instrumental music, and "quadro", a variant of orchestra basis. It describes the non-typical instrumentation, continuing its development since the Baroque period. It determines the classification for the chamber orchestra structure: individualized four-voice string parts, wind instruments as a timbre component. This orchestra is defined as a classic type, divided into two kinds: string and combined. The presence of symphonic and chamber orchestras worked for the formation of two performing styles: symphonic and chamber.

Keywords: classicism, Haydn, Mozart, chamber orchestra, full (symphonic) orchestra, quantitative and structural instrumentations, symphony, divertissement, serenade, "nocturne", "quadro", functional music, string and combined types of chamber orchestra.

Research area: Art History.

In the second half of the $18^{\text {th }}$ century musical Classicism reached its culmination point. Classicism aesthetics was nourished on the fruitful grounds of humanistic Enlightenment ideas. The enlighteners considered human at large not only as the top creation of nature, but also as a great world reformer, enjoying an enormous potential of self-perfection. That was the Classicism that caused the interest and admiration of artists. Demonstrating the ideal appetence of the classicism composers on the example of Mozart, I. Sollertinsky wrote, that Mozart, "like many other disciples of the $18^{\text {th }}$ century's progressive "intelligentsiya", raised with the ideology of encyclopaedists, Enlightenment philosophy, and Russo, was really convinced that he was witnessing the beginning of a new era, when the social barriers collapse... and feudalism was doomed... The idyll Mozart recognized was the final aim of his social and politic dreams: the global fellowship of people and peoples, based on some universal humanism" [Sollertinsky: 53-54]'.

Analyzing the music style of the epoch, S. Skrebkov notices that it was the period of rejoice for individualized melodicism and the "texture that became homophonic in its core... Polyphony got concentrated in the accompaniment. This was

(C) Siberian Federal University. All rights reserved

* Corresponding author E-mail address: preisman@list.ru 
the beginning of the progressive accompaniment polyphonisation epoch. Figured polyphony, timbre polyphony, and sound layers' polyphony were flourishing. A new level was reached by multi-theme polyphony; since those times, we can find combinations of several individualized themes, sometimes working for expression of the whole ensemble of artistic appearances" [Skrebkov: 20].

Withsuchabundanceofaestheticinformation, the permanently urgent art problem of form and content could be solved only by means of wide generalization of human essence in time and space. Classicism embodied its solution in the harmony of unified cyclic form of a symphonic sonata as a spatial rhythm, developing and complementing the Baroque cyclic form. The symphonic sonata cycle was the reflection of symmetry in music as the aesthetic ideal of Classicism. Concise, harmonic and multifunctional, it could work for the pieces of various genres: symphony, quartet, piano trio, instrumental concert or sonata ${ }^{2}$.

Making areferencetoDahlhaus, M.Lobanova remarks, that the "musical Classicism created the 'universal harmony' its predecessors had been dreaming of. In the perfect balance of Vienna musical classics, principles of intelligibility of an aesthetic object were proclaimed, the conceptions of a general language, set style, genre, and composition technique, previously intertwined in the 'exquisite antithesis harmony' of baroque, were finally distinguished. In many ways, it became possible due to the conception of 'absolute music' which was established at the end of the $18^{\text {th }}$ century and anticipated the emancipation of music as art, its immanent logic and sense, independent from on any "intermediary" [Lobanova: 44].

Search for a generalised and unified form for idea exposition, which would regulate the diversity of expressive means for individualizing the thematic invention at all levels: melody, timbre, and performing methods, encouraged structural normalization and unification of the performing mechanisms: full orchestra, quartet, piano trio, sonata duet, etc.

The means of orchestra expression were also developed. F. Tourte and his son improved the bow, making it possible to play wide cantilena and to do light, "airy" strokes on string instruments. Mozart made clarinets ${ }^{3}$ a part of orchestra and introduced some trombones. Due to the presence of several same-kind instruments with various timbre and range within a group, strings, woodwinds, and brass could play any chord with voices dispersed throughout different ranges. The functions of instrumental parts in the chord were clearly set up. As an instrument, the timbre of which worked for thickening the chord balance, harpsichord finally lost its relevance.

Orchestras were expanded both quantitatively and structurally. In the year 1770, the Salzburg Orchestra Mozart worked with consisted of at least 30 performers: $10-12$ violins, violas, 2-3 cellos, 2-3 double basses, 2-3 oboes or flutes, 3 horns, trumpets, trombones, timpani. It is remarkable that trumpet players were admitted to the orchestra only if they could also play viola [Abert: 341]. The instrumentations for which Mozart composed the major part of his Vienna period operas and orchestra pieces, were also big: strings, 1-2 flutes, 2 oboes, 2 horns, 2 trumpets, timpani. The orchestra playing in the Paris "spiritual orchestras" in the year 1773, consisted of 58 performers. The Prussian king orchestra in Berlin in the year 1787 consisted of 61 performer. The number of musicians playing in opera orchestras was even larger. The big orchestra structure was established: strings (1013 first violins, 10-11 second violins, 4-6 violas, 4-6 cellos, 4 double basses), winds ( 2 flutes, 3-4 oboes, 2 clarinets, 3-4 bassoons, 2-4 horns, 2 trumpets), percussion (1 person), i.e. paired instrumentation, sometimes with a slightly expanded woodwind group. 
The Manheim School composers also created pieces for the instrumentations considered large for the period. According to A. Carse, in the year 1782 Manheim Orchestra consisted of up to 60 performers, who included, sometimes, over 20 violinists, 3 violists, the number of who could be always increased as the violinists could also play viola, 4 cellists, 3 double bassists, 3-4 musicians playing woodwinds, 4 trumpeters, and percussionists [Carse: 23].

Together with the large ones, there were also smaller orchestras, consisting of 20-14 musicians and less [Carse: 18 - 27].

Summarizing the data provided by A. Carse, M. Pincherle, Ch. Terry [Carse, Pincherle, Terry], we observe that within the studied period nearly a half of the orchestras existing in Europe belonged to such a kind. Notice, that this number does not include the opera orchestras and troops engaged with both opera and concert activities. The majority of small orchestras played in Germany. Later they became wide-spread in Poland, Austria, France, Chechia. There is information about such orchestras' performance in Spain and Denmark, and, at the end of the century, in Russia as well.

Therefore, the tendency for simultaneous development of larger and smaller orchestras was preserved and progressed. The gap between them was growing wider and deeper.

Large orchestras, the ones we may now call symphonic, operated with the density of sound (which was provided by the synthesis of unisonous string groups consisting of quite a large number of performers, with the brass and woodwinds), the contrasts of sounding mass and timbre. The crystal-like monolith of the symphonic orchestra with its clear texture was appropriate for the welldefined structure of the unified symphonic sonata cycle, expressing the highest level of generalizing the human being into the "universal harmony".

The chamber orchestra structure was less clear due to the flexibility of winds. But playing in chamber orchestra implied higher performing skills, which was required by the less number of performers, so that the significance of each musician was inversely proportional to their number. The main performing idea of the chamber orchestra was simultaneous solo, and soloist unison for small string groups. Often chamber orchestras consisted of the best symphonic orchestra performers and officially belonged to the symphonic orchestras [Carse: 23 - 27].

However, there were many "permanent" orchestras active at the same time. Their existence was mostly determined by the social and material reasons: they included as many musicians as they were able to pay. And the orchestras played the pieces, the parts of which corresponded to their available instrumentation.

Turning to the orchestra music of the period and trying to differentiate the artistic purposes of its apparatus, it is impossible to determine the orchestra type the piece was written for from the instrument list provided in the score. Until the $20^{\text {th }}$ century, the score did not include any intended quantitative features of the orchestra, and up to the late $19^{\text {th }}$ century all instrument names were indicated in singular. The scores only defined the timbre structure of the orchestra, while the piece could have been composed for a symphonic orchestra, or a chamber orchestra with expanded winds, or a large orchestra with a limited number of winds. The pieces could be performed by musician groups of different sizes. It was possible to reveal the artistic function of the orchestra only by correlating the number of its musicians with the structure and genre of the performed pieces, which required a certain performing apparatus.

Classicist chamber orchestra development was mostly determined by the longing for selfexpression, subsequent from the Enlightenment ideas, embodied in the active amateur musicmaking on the basis of functional music ${ }^{4}$. The main peculiarity of the period was the emergence 
of the new genres, the origins of which go back to functional music. The components of the opuses belonging to the genres were small pieces, mostly of dancing, marching or singing types, united into cycles called serenades, cassations, and divertissements, included into the widely spread and widely interpreted notion of "nocturne" [Abert: 186]. The number of parts in a nocturne could vary, and the structure of the cycle was very flexible. F. Abert writes: "Here, too, we find signs of the occasional character of the medium as a whole: if the performers included outstanding soloists among their number, the composer would have no hesitation in including one or more movements in which they could display their abilities to the full [Abert: 341]. Nocturne was especially popular in Vienna.

As a rule, nocturnes were performed by small orchestras consisting of four sting parts and two horn parts. L. Nowak refers to such instrumentationas "quadro". This instrumentation was suitable for performing a symphony, a cassation, or a divertissement. In the event if the string group was larger than a quartet, the "quadro" instrumentation was expanded, turning into a small orchestra. The same opus written for a "quadro" acquired a new "sounding self" every time, depending on the number of performers [Nowak: 33 - 34].

The structural regulation of the string group as a unified basis for performing ensembles, determined by Classicists, and the conception of Nowak that the instrumentation of a "quadro" was sufficient for performing a symphony leads us to the following string layout of a "quadro": first violin, second violin, cello (or cello and double bass). Apparently, the essential presence of two horns is explained by the fact that, with appropriate slides, they could be used for performing music composed in any key.

In the year 1761, Haydn was admitted by Paul II Anton Esterházy in Eisenstadt. The Esterházy orchestra consisted of 4 violins, viola, cello, double bass, 2 oboes, 2 bassoons: in total, there were 12 performers, and 7 of them played strings. If it was required to increase the winds section, some musicians from the military orchestra were invited. The Esterházy orchestra of the year 1761 was a small one. Commenting the Esterházy instrumentation, L. Nowak says: "No one dared to play flat in such an orchestra" [Nowak: 158]. Haydn worked with this orchestra until the year 1766, when the summer residence of Nikolaus Esterházy was moved to Esterháza, where a 400seat opera theatre was built and the orchestra was expanded to 25 people.

During 1761-1766 Haydn created around thirty symphonies (to be precise, No. $3-31)^{5}$. The majority of them were written for the instrumentation consisting of strings, two oboes and two horns. The sound of such an orchestra was well-balanced: strings constituted around two thirds of the total number of performers.

However, in the Symphonies No. 6 and 8 the listed instruments were complemented by flute and bassoon, in No. 20 - by two trumpets and timpani, in No. 24 and 30 - by flute, in No.13 and 31, besides strings, a flute and four horns appeared. As we can see, the mentioned eight symphonies were written for instrumentation with quite a big number of winds divided into two groups: brass and wood winds. To balance the sound, it required much more strings than the Haydn orchestra had. It is absolutely evident that the composer, creating the symphonies for the orchestra he had "at hand", could foresee the increase of the number of strings.

The "quadro", in which Haydn and Mozart heard the spirit of the epoch, attracted composers being an example of a small mobile orchestra body evaluated by everyday musical practice, providing wide expression apparatus, inspiring for composing chamber orchestra pieces. Back then, with the larger orchestras available, both 
Haydn and Mozart wrote chamber orchestra music for the instrumentation apparatus based on "quadro" principle.

For chamber orchestra Haydn composed several divertissements and six menuets.

The fact that Haydn's chamber orchestra works were composed for an orchestra, not an ensemble, is proved by the presence of $\mathrm{Ba} \beta$ part in the score, which implied the unison or magadizing cello and double bass parts. The fact the pieces were written for a chamber orchestra is witnessed by the thematic invention and the impact of functional music, orientation of the performing apparatus on "quadro" principle.

However, Haydn saw "quadro" only as a reference, not an ideal for the chamber orchestra structure. For this reason, he introduced drastic changes into the parts' composition to bring it into compliance with his creative needs. Therefore, Divertimenti No. 21, 22 and Six Minuets were written specifically for "quadro". Divertimenti No. 1 and 2 were written for strings, flute and oboe (two woodwinds instead of two horns), No. 2 and 6 - for strings ("quadro" without horns). Divertimento No. 39 has the author's comment "for 2 doubled violins and a bass in various chamber instrumentations" [Hoboken: 325], which proves that what Haydn meant was the quantitative variability of typical "quadro" strings.

Haydn's chamber orchestra is "homophonic". Its basis consists of strings and two, or, less frequently, four wind parts. The functions of every part are strictly divided within the string group. As a rule, the main theme is entrusted to the first violins. The second violins and viola play, mainly, the middle parts of the harmonic complex, and cellos play the bass $a$ due with double basses. The winds' role is not reduced to doubling the strings' part. The winds do not only "maintain the chords"; they are charged with independent melodic or counterpoint constructions. Quite often there are timbre oppositions of strings and winds (Divertimenti No. 1, 11, 21, 22, minuet cycles etc.) in Haydn's works. It means that the individualization process of thematic invention in them encompasses the whole wind group as a timbre complex instead of some separate wind instruments.

Mozart wrote a series of divertissements, several serenades, cycles of menuets and contredanses for chamber orchestra. In these works he acts as a daring and witty innovator. Only four divertissements (K-246 $\left.{ }^{c}, 247,271,320\right)$ and Two Minuets K-61 ${ }^{\mathrm{a}}$ were written specifically for a "quadro".

Expanding his timbre palette, the composer varies the combinations and quantities of the used winds, introduces some percussion and modifies the string group composition. So, Divertimento K-63, contredanse "Das Donnerwetter" K-534, Six Minuets K- $130^{\mathrm{a}}$ were written for strings, two oboes, and two horns; Contredanse K-535 ${ }^{\mathrm{c}}$ - for stings, flute, oboe, bassoon, horde; Contredanse for basset horn and orchestra K-584 ${ }^{\mathrm{c}}$ - for strings, two flutes and two horns. In some works the composer settles for three parts of strings omitting violas, but manipulating winds and percussion: flute and snare drum in Contredanse K-609; two flutes and two horns in Contredanse K-610; two clarinets and one bassoon in Contredanse "La Battaille". Into Divertimento K-63 for strings, two oboes and two horns, he introduces two viola parts. In the second part of Sinfonietta D-dur, he foresees cello divisi.

Mozart also considers the peculiarities of the "occasional medium art". In this regard, the remark of G. Abert on Serenade D-dur (KV 320) seems especially interesting: "In the autograph score, the flautino part has been left blank in the first trio: perhaps the player was intended to improvise it" [Abert: 319].

Just like Haydn who did not limit himself to the "quadro" framework, Mozart composed some 
of his works for strings only: "Eine Kleine Nacht Musik"K-525, cycles of menuets and contredanses. Several opuses were made for three-part strings harmony, two violins and a bass, like Six German Dances K-606, which reveals the reference to the old form of Italian instrumental improvisation, serving as a trio sonata prototype.

Mozart experiments with spatial and sounding volumes: Serenade K-239 for two Orchestras, one of which includes timpani, Rondo Concertante $\mathrm{K}-260^{\mathrm{c}}$ for four quadros, the score of which contains the author's remark: "Viermal 2 Violinen, Viola, Baß und 2 Horner"?.

In the year 1771, Divertimento K-113 for strings, two clarinets and two horns was written, where Mozart introduced clarinets for the first time.

Composer often turns to descriptive chamber orchestra music. The titles ascribed to the pieces by Mozart prepare the listener to a humoristic plot: Divertimento "Ein musikalischer Spa $\beta$ ” K-522, Contredanses "La Battaille" K-535" and "Das Donnerwetter" K-534. Contredanse K-609 has no descriptive title. But in the first part of the opus written several years after "Figaro's Marriage" came on stage, there plays a theme from the popular Figaro's aria "Farfallone Amoroso". Together with the implied lyrics of the aria, the introduction of a snare drum, an essential instrument for creating military ambience in music, together with strings and flute, reveals the humoristic content of the Divertimento. And from the point of view of the interconnection between the chamber orchestra and functional music, the situation turns out to be ironically reverse: it is not the functional music that nourishes the professional music, but the professional, though brought to everyday life through some intermediaries, determines the understanding of the everyday life music written by the composer.

Mozart thinks of functional music as of an inspiration source for professional composition, generalizes it in the widest sense of the word. His chamber orchestra pieces are the crystals of ingenious aphorisms. They enrapture and astonish. So, speaking of Divertimenti F-dur K-247 and B-dur K-271 , G. Abert emphasizes the depth of their content and the ingenuity that "merge all the instruments together into the authentic chamber music style" [Abert: 48]. The researcher remarks that Allegro of Divertimento K-247 "gives much space to counterpoint", and the Divertimento K-271 "scales even higher peaks... to create a genuine chamber music style" [Abert: 48]. In Divertimento K-271 ${ }^{\mathrm{c}}$ he admires "the powerful sense of enjoyment evoked by its opening movement, with its rustic ländler ${ }^{8}$; the fine brushwork in its second movement, which is cast in the form of a set variations; the witty and manly minuets; the broadly flowing, genuinely Mozartian cantilena of the adagio, ... and the finale, one of the most ebullient final movements that Mozart ever wrote [Abert; 48].

Thetransformationscale of Mozart'schamber orchestra music is wider than that of Haydn's. The specificity of the composer's individual language, polyphonic development elements, brilliance of violin parts, introduction of themes with delicate variations into Divertimenti K-271", K-320", and Serenade K-361, the spiritual chastity of menuets reveal the mediated materialization of the themes and forms of functional music. In Nocturne K-269 Mozart goes deeper in the genre reflection: the poetic water colours of Andante create an original emotional background, on which the graceful Allegretto and the contrasting decisiveness of the menuet are laid. The sequence of musical appearance dynamics is strictly determined in Divertimento K-125": the calm Andante anticipates the impulsive Allegro di molto followed by audacious Allegro assai, completing the opus. Divertimenti K-125 and $\mathrm{K}-125^{\mathrm{e}}$ are composed in the form of a laconic cycle: Allegro-Andante-Presto. At the same time, 
Mozart expands his "Eine Kleine Nacht Musik" beyond the divertimento framework, bringing it to the clearness and elegance of the symphonic sonata cycle? .

Nocturnes by Haydn and Mozart, abundantly reflecting a great layer of functional music culture, based on its general semantics, raise the functional music up to the level of poeticized artistic generalization, thereby expanding its meaning, enriching its language and improving its shape. The process is re-orientation of functional genres from reflection to generalization of the communal musical background, and, thereby, transformation of functional genres into academic ones. The process of re-orientation and transformation of genres is continuing during the subsequent epochs, too.

A special place in the chamber orchestra works by Mozart is taken by Serenade B-dur $\mathrm{K}-361=370^{\mathrm{a}}$ for thirteen instruments with individual parts: 2 oboes, 2 clarinets, 2 basset horns, 3 horns, a bass horn, 2 bassoons, double bass. This absolutely unusual and daring irregular instrumentation, experimental in themes and timbres, just like the Six Sonatas and "The Faithful Shepherd" by Vivaldi, anticipates the free selection of instrumental timbres that began in the composing practice of the $19^{\text {th }}$ century and became a common practice in the $20^{\text {th }}$. Studying Serenade B-dur as an experience of actualizing diverse-themed polyphony, it becomes evident that individualization of the themes brought the individualization of parts up to the irregularity of instrumentation.

In the year 1775 Mozart created five violin concertos, and in the year 1777 the sixth concerto saw the light. Revealing a dance-like base in their themes, I. Yampolsky arrives at a logical conclusion that the composer, attracted by the dance environment, turned to the soloing violin as to an instrument popular in everyday music genres, which binds the violin concertos by Mozart to his divertimenti and serenades [Yampolsky: 21]. The closeness of the concert motives to functional music determined the timbre limits (strings, two oboes, two horns) and, evidently, the limits in the instrumentation quantity. It is appropriate to suggest that the violin concertos were created for a chamber orchestra.

Just like the other works by Mozart in other genres, the chamber orchestra pieces serve as the most refined examples of classicist music.

A classicist chamber orchestra acts as a mobile apparatus used for composers and performers for expressing theirimmediatereaction to the new aesthetic impressions revealed in the lively transformability of the everyday music background, i.e. the apparatus for performing the pieces based on the functional music material. Its structure is typed: strings with each part's role differentiated in the four-voice harmony and winds established as a timbre component.

Such chamber orchestra may be referred to as classic. According to its instrumentation, a classic chamber orchestra is sub-divided into two types: string and mixed. String orchestra: a group of first violins, second violins, violas, cellos doubled with double bass, harpsichord. Mixed orchestra: string group, two-four winds (commonly, two oboes and two horns), harpsichord. Variability of winds is typical for such an orchestra. The number of participants in the classic chamber orchestra is $12-17$ people. In the $20^{\text {th }}-$ early $21^{\text {st }}$ centuries such instrumentations became widely popular in professional, academic and amateur music-making [Preisman: 209 - 255].

Conceiving orchestra music of the late $18^{\text {th }}$ century, we notice the evident formation of two performing styles: symphonic and chamber orchestra styles. The components of their integrity are the unisonous performance of each string part within the homophonic texture and the combination of string and wind timbres within the timbre polyphony scales. 
In symphonic performance, the symphonic sonata cycle with its key unity and architectonic symmetry both in each component and in the piece as a whole, implying authoritative conductor interpretation, where the diversity of music appearance is revealed by the articulation of sound, its horizontal and vertical dynamics, phrasing within the framework of the tempo and dynamics of a music part, presents itself as an integrative concept of generalizing human force in time and space.

In chamber orchestra performance going back into the everyday music-making of the past, there are no strict regulations for its form and content. The liberal cycle structure, sometimes combining the parts, inhomogeneous in the texture and character and unlimited in number, not implying the conductor's dictate, sets the lively, improvisational manner of performance concerning the intonation, rhythm, tempo and sound producing, expressing thereby the subjective understanding of dramaturgic collisions. The meaning concepts of chamber orchestra music are multiple and diverse.

In a classic chamber orchestra the unison performance of each string part by a small group of musicians (which correlates the classic chamber orchestra with the Corelli chamber orchestra) requires the integrity of technical understanding of the piece by all the musicians constituting the group. The chamber orchestra style of performance of the late $18^{\text {th }}$ century, preserving the heritage of baroque concerto character, multiplies it by its unisonous character, thereby determining a new quality of performance: a soloist unison ensemble.

\footnotetext{
Analysis of culture within the spatial and temporal coordinate system and review of existing researches dedicated to systematization of the semantic fields of cultural space are the subjects of the work by G.D. Zabrodina and N.L. Petrova "Spatial and Temporal Aspect of Artistic Culture Appearance Studies" [Zabrodina, Petrova: 6 - 11].

2 The three-part form of classicist concerts, trios, sonatas, is the sonata and symphonic cycle without one of the two last parts.

3 The clarinet took its permanent place in the orchestra in the year 1788, when Mozart included its part into his symphonies Thirty Nine and Fourty One, though the first experience of introducing clarinet into the orchestra happened in 1755 in the symphonies with clarinet and double bass by J. Stamitz.

4 In his "Musical Travel" Ch. Burney wrote about Czech school students who used to unite into small choirs and orchestras 18-20 people each with their violins, cellos, oboes, horns and bassoons. Such orchestras would give concerts in the streets, play at festivals and funerals, take part in summer masses and home music parties [Burney: 145].

$5 \quad$ Numbers and names of the works are indicated according to A. Hoboken catalogue [Hoboken].

6 Numbers and titles of works are indicated according to L. Köchel catalogue, where the numeration is chronological [Köchel].

Tradition of composing for several orchestras or ensembles originates from antiphonal singing.

8 Choreographic description of ländler have been known since the $16^{\text {th }}$ century. However, only due to the chamber orchestra pieces of Mozart, the genre of landler reached the peak of its popularity.

9 It is suggested that based on the genre approach historicism, this work should be referred to not by its common name of "Small Night Serenade" but with the author's descriptive title, the "Small Nocturne".
}

\section{References}

1. Abert, H. W.A. Mozart / Translated from German into Russian and commented by K.K. Sakva. $2^{\text {nd }}$ edition. Moscow: Muzyka, Volume 1, book 1. 1987. 534 p. Volume 1, book. 2. 1988. $606 \mathrm{p}$.

2. Burney, Ch. Musical Travel. Moscow, Leningrad: Muzyka, 1976. 290 p.

3. Zabrodina G.D., Petrova N.L. Spatial and Temporal Aspects of Studying the Artistic Appearance of Culture. Voprosy kul'turologii. Moscow: 2013, No.4. 6 - 11.

4. Lobanova M. Musical Style and Genre: History and Modernity. Moscow: Sov. Kompozitor, 1990. $312 \mathrm{p}$.

5. Nowak L. J. Haydn. Translated from German. Moscow: Muzyka, 1973. 488 p. 
6. Preisman E.M. On Music and Musicians: Times and Events. Krasnoyarsk State Academy of Music and Theatre. Krasnoyarsk, 2013. 260 p.

7. Skrebkov S. Artistic Principles of Musical Styles. Music and Modernity. Moscow, 1965. Volume 3., P. 3 - 31.

8. Sollertinsky I. Musical and Historical etudes. Moscow: Gos.muz.izdat., 1956. 164 p.

9. Forkel, J.N. J.S. Bach, his Life, Art and Work. Translated from German by V.A. Yerokhina. Moscow: Muzyka, 1967. $111 \mathrm{p}$.

10. Yampolsky I.I. Violin Concertos by Mozart. Moscow: Muzgiz, 1961. 39 p.

11. Carse A. The orchestra in the XVIII-th century. - Cambrige: W.Heffer, 1940, 1950. 176 p.

12. Hoboken A. Joseph Haydn: Thematish-bibliographisceszusammengestellet. Bd. 1. Mainz: B.Schott'sSöhne, 1957. $848 \mathrm{~s}$.

13. Köchel Z. Chronologisch-tematischesVerzciohnis der WerkeW.A.Mozart. Leipzig: VEB Breitcopt. Härtel, 1969. 984 s.

14. Pincherle M. L'orchestre da chamber. Paris: Librarie Larousse, 1948. 74 p.

15. Terry C.S. Bach's orchestra. London: Oxford university press, 1958. 250 p.

\title{
Камерный оркестр
}

\section{в творчестве венских классиков}

\author{
Э.М. Прейсман \\ Красноярская государственная академия музыки и театра \\ Россия, 660045, Красноярск, ул. Ленина, 22
}

Статья посвящена развитию камерного оркестра в творчестве Гайдна, Моцарта, других композиторов. Исследуются составы больших и мальх оркестров периода (количественный и тембровый), исполняемые произведения. Трактуются понятия «ноктюрн», обозначающее в то время совокупность бытовой инструментальной музыки, и «квадро» - вариантная основа оркестров. Указывается на продолжающий свое развитие со времен барокко ненормированный состав. Определяется типизация структуры камерного оркестра: струнные с индивидуализацией каждой партии в четырехголосном складе, духовые - как тембровое слагаемое. Данный оркестр определяется как классический тип, подразделяемыий на два вида: струнный и смешанный. Наличие симфонического и камерного оркестра послужило формированию двух исполнительских стилей - симфонического и камерно-оркестрового.

Ключевые слова: классищизм, Гайдн, Моцарт, камерный оркестр, большой (симфонический) оркестр, составы количественные и структурные, симфония, дивертисмент, серенада, «ноктюрн», «квадро», бытовое музицирование, струнный и смешанный виды камерного оркестра.

Научная специальность: 17.00.00-искусствоведение. 